\title{
Penerapan Metode Analytical Hierarchy Process (AHP) dalam Menentukan Ras Ayam Serama
}

\author{
Application of Analytical Hierarchy Process (AHP) \\ in Determining Ras of Serama Chiken
}

\author{
Wirhan Fahrozi \\ Universitas Potensi Utama \\ E-mail: wirhanfr@gmail.com
}

\begin{abstract}
Abstrak
Ayam Serama merupakan jenis unggas hias baru yang berukuran sangat kecil dan ringan dan merupakan hasil persilangan ayam katai, ayam serama ini merupakan jenis unggas hias yang sedang popular saat ini di Indonesia. Sehingga menjadi pertimbangan bagi para pecinta ayam serama untuk mendapatkan informasi tentang ras ayam serama, informasi yang dapatkan nantinya dapat menjadi pedoman bagi para pecinta ayam serama dalam menentukan ras ayam serama dengan akurat, dimana saat ini masih perlu dilakukan pembahasan untuk penilaian ras ayam serama. Dalam hal ini diperlukan analisa yang tepat untuk mempercepat proses identifikasi dalam menentukan rasa ayam serama. Oleh karena itu dibutuhkan sebuah model yang dapat menggambarkan seluruh sistem komputerisasi yang mendukung dalam proses pengambilan keputusan. Sistem pendukung keputusan dengan menggunakan Metode Analytical Hierarchy Process ini melakukan penilaian pada setiap ayam dengan ragam kriteria, dan perubahan nilai bobot. Hal ini berguna untuk memudahkan pengambilan keputusan yang terkait dengan identifikasi ras ayam serama, sehingga akan didapatkan ayam yang paling layak dinyatakan sebagai ras ayam serama.
\end{abstract}

Kata Kunci - Analytical Hierarchy Process, Sistem Pendukung Keputusan, Ayam Serama.

\begin{abstract}
Chicken serama is a new ornamental poultry sized very small and light is the result of a cross chicken dwarf, chicken serama it is the type of ornamental poultry being popular current in indonesia. So that it becomes consideration for the lovers chicken serama to get information about race chicken serama, information get will have become guidelines for the lovers chicken serama in determining race chicken serama accurately, where the current is still needs to be discussed to the assessment of chicken serama race. In this is the right to expedite the identification in determining chicken serama. Hence needed a model could describe the whole system computerized that supports in the decision-making process.The support system decision by using the method analytical hierarchy process conducts judgment on every chicken with its diversity of criteria, and fluctuations in the weight .It is useful to ease decision-making associated with identification race chicken serama, so that it will obtained chicken most worthy expressed as race chicken serama.
\end{abstract}

Keywords - Analytical Hirearchy Process, Decision SupportSystems, Serama Chicken. 


\section{PENDAHULUAN}

Ayam serama merupakan jenis unggas hias baru yang merupakan hasil persilangan yang dilakukan oleh seorang peternak asal klantan, bernama Mr.Wee Yean Ean. Mulanya, Mr Wee mencoba menyilangkan ayam katai kaki panjang biasa disebut ayam kapan dengan ayam ras Modern Game Bantam, hasil persilangan tersebut dikawinkan dengan jenis ayam sutera (Silkie Bantams). Perkawinan ini menghasilkan ayam sutera berpostur kecil. Mr. Wee mencoba mengawinkan hasil dari percobaan kedua dengan ayam katai Jepang dan berhasil mencetak ayam mungil dengan bobot tubuh tidak lebih dari 500 gram. Hasil persilangan ini diberi Nama serama [1].

Ellya dalam penelitiannya juga menerapkan metode AHP untuk penilaian kinerja dosen dengan menggunakan metode AHP untuk pemilihan kinerja dosen yang berkualitas, di mana penelitian tersebut telah berhasil meningkatkan kinerja dosen-dosen [2]. Ngawati dan Ira menggunakan metode AHP sebagai analisis masalah yang berkaitan dengan pemilihan supplier yang terbaik [3]. Penelitian yang dilakukan Nur dan Armandira Menghasilkan sistem pendukung keputusan perencanaan strategis kinerja instansi pemerintah menggunakan metode AHP, telah banyak membantu bagian dalam instansi tersebut untuk menentukan kebijaksanaankebijaksanaan dalam perencanaan strategis [4]. Sebuah sistem pengambilan keputusan dengan menggunakan metode AHP untuk menentukan urutan mahasiswa berprestasi [5]. Dalam proses penilaian pegawai haruslah dengan metode dan tools yang tepat sehingga menejemen tidak salah dalam menentukan pilihan keputusan. Metode yang digunakan dalam menganalisis data adalah metode AHP [6].

\section{METODE PENELITIAN}

Penelitian ini dilaksanakan menggunakan data AYAM KATAI/MINI yang diambil dari CMF (Cah Medan Farm) yang merupakan salah satu tempat penangkaran ayam katai di Kota Medan. Data-data ayam seperti pada Tabel 1 akan dijadikan sebagai nilai dasar untuk perbandingan kriteria dan alternatif.

Data tersebut akan diolah dan dilanjutkan dengan menggunakan meode Analytical Hierarchy Process (AHP) dimana software yang digunakan untuk mendapatkan hasil keputusan adalah Expert Choice.

Tabel 1. Contoh Data Ayam Serama yang diusulkan

\begin{tabular}{|l|l|l|l|}
\hline No & \multicolumn{1}{|c|}{ Nama } & \multicolumn{1}{c|}{ Pemilik } & Alamat \\
\hline 1 & AYAM A & BUDI/CHENXIN & Medan \\
\hline 2 & AYAM B & BUDI/CHENXIN & Medan \\
\hline 3 & AYAM C & BUDI/CHENXIN & Medan \\
\hline 4 & AYAM D & BUDI/CHENXIN & Medan \\
\hline
\end{tabular}

\subsection{Analisa Kebutuhan Data}

Dalam menetapkan ras ayam serama, langkah pertama yang harus dilakukan adalah menentukan kriteria-kriteria yang yang digunakan, kriteria yang digunakan adalah pembobotan penilaian terhadap kriteria-kriteria.

\subsubsection{Analisa Kebutuhan Data Alternatif}

Ada empat alternatif yang digunakan didalam penentukan ras ayam serama pada CMF (Cah Medan Farm) yaitu:

1. Ayam A

2. Ayam B 
3. Ayam C

4. Ayam D

\subsubsection{Analisa Kebutuhan Data Kriteria}

Ada tiga kriteria yang digunakan didalam menentukan ras ayam serama yaitu:

1. Penilaian Trah, adalah bukti yang terkait dengan silsilah atau garis keturunan ayam.

2. Penilaian Postur adalah bukti yang terkait dengan penilaian postur tubuh yang dimiliki oleh ayam serama.

3. Penilaian Assesoris adalah bukti yang terkait dengan penilaian ciri khas ayam serama meliputi assesoris yang dimiliki, meliputi warna, balung, lawi, sayap, dll.

4. Style adalah bukti yang terkait dengan penilaian ayam aktif atau gaya.

\subsection{Analisa Metode Analytical Hierarchy ProcessDalam Menentukan Ras Ayam Serama}

Analytical Hierarchy Process (AHP) merupakan suatu model pendukung keputusan yang dikembangkan oleh Thomas L. Saaty. Metode AHP telah banyak digunakan untuk membantu pengambilan keputusan [7]. Analytic Hierarchy Process (AHP) adalah teori pengukuran melalui perbandingan berpasangan dan tergantung pada penilaian dari para ahli untuk mendapatkan skala prioritas. Perbandingan yang dibuat menggunakan skala penilaian mutlak yang mewakili, berapa banyak lagi, satu elemen mendominasi yang lain sehubungan dengan atribut yang diberikan. Penilaian mungkin tidak konsisten, dan bagaimana mengukur inkonsistensi dan meningkatkan penilaian, bila mungkin untuk mendapatkan konsistensi yang lebih baik adalah kekhawatiran dari AHP. Skala prioritas yang berasal disintesis dengan mengalikan dengan prioritas node induk dan menambahkan untuk semua node tersebut [8].

Model pendukung keputusan ini akan menguraikan masalah multi faktor atau multi kriteria yang kompleks menjadi suatu menjadi suatu hirarki. Hirarki didefinisikan sebagai suatu representasi dari sebuah permasalahan yang kompleks dalam suatu struktur multi-level faktor, kriteria, sub kriteria, dan seterusnya ke bawah hingga level terakhir dari alternatif [9].

Dalam kasus ini dapat diperlihatkan tahapan penetapan ras ayam dengan menggunakan metode AHP seperti pada Gambar 1. Adapun langkah-langkah yang dilakukan sebagai berikut:

1. Pecahkan atau uraikan sebuah keputusan dalam dimensi yang berbeda. Tahapan ini merupakan proses pengenalan atau identifikasi awal terhadap objek yang akan diteliti. Adapun objek-objek tersebut yaitu:

a. Tujuan

Penetapan Ras Ayam Serama ini bermanfaat untuk membantu CMF (Cah Medan Farm) dan masyarakat umum untuk mengetahui ras ayam serama yang merupakan ras ayam kerdil/mini yang baru.

b. Kriteria

Kriteria merupakan atribut-atribut yang mendukung untuk memutuskan ras ayam serama sesuai dengan kasus yang di teliti. Berikut ini adalah kriteria-kriteria yang digunakan dalam penelitian ini:

1. $\mathrm{PT}=$ Penilaian Trah

2. $\mathrm{PP}=$ Penilaian Postur

3. $\mathrm{PS}=$ Penilaian Style (gaya)

4. $\mathrm{PA}=$ Penilaian Assesoris

c. Alternatif

Alternatif merupakan objek penelitian yang akan diproses untuk penentuan terhadap suatu kasus. Adapun alternatif yang digunakan pada penelitian ini yaitu:
1. Ayam A
2. Ayam B
3. Ayam C
4. Ayam D 
Citec Journal, Vol. 3, No. 3, Mei 2016 - Juli 2016

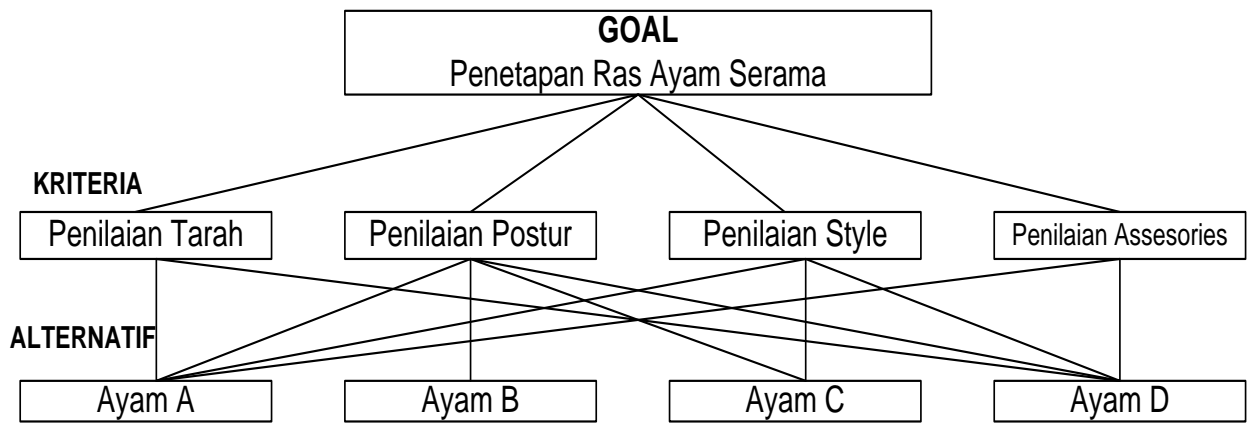

Gambar 1. Struktur Hirarki AHP Penetapan Ras Ayam Serama

2. Menentukan bobot relatif pada masing-masing dimensi.

Tahapan ini pemberian bobot menggunakan model AHP (Analytic Network Process). Menurut Thomas L. Saaty skala kuantitatif 1 sampai 9 untuk menilai secara perbandingan tingkat kepentingan suatu elemen dengan elemen lain dapat dilihat pada Tabel 2.

Tabel 2. Tabel Penilaian Perbandingan Berpasangan

\begin{tabular}{|c|l|l|}
\hline $\begin{array}{c}\text { Tingkat } \\
\text { Kepentingan }\end{array}$ & \multicolumn{1}{|c|}{ Definisi } & \multicolumn{1}{c|}{ Keterangan } \\
\hline 1 & Sama Penting & Kedua elemen sama pentingnya \\
\hline 3 & Sedikit lebih penting & Elemen yang satu sedikit lebih penting \\
\hline 5 & Lebih penting & $\begin{array}{l}\text { Elemen yang satu esensial atau sangat penting (lebih } \\
\text { penting) ketimang elemen yang lainnya }\end{array}$ \\
\hline 7 & Sangat penting & $\begin{array}{l}\text { Satu elemen jelas lebih penting dari elemen yang } \\
\text { lainnya }\end{array}$ \\
\hline 9 & $\begin{array}{l}\text { Mutlak sangat } \\
\text { penting }\end{array}$ & $\begin{array}{l}\text { Satu elemen mutlak lebih penting ketimang elemen } \\
\text { yang lainnya }\end{array}$ \\
\hline $2,4,6,8$ & Nilai tengah & $\begin{array}{l}\text { Nilai-nilai diantara dua pertimbangan yang } \\
\text { berdekatan }\end{array}$ \\
\hline Kebalikan & $\begin{array}{l}\text { Jika aktivitas } i \text { mendapat suatu angka bila dibandingkan dengan suatu aktivitas } \\
j . \text { Maka } j \text { mempunyai nilai kebalikannya bila dibandingkan dengan aktivitas } i\end{array}$ \\
\hline
\end{tabular}

Setelah pemberian bobot maka dilakukan uji Konsistensi Indeks dan Rasio hal ini dapat mengarah pada ketidakkonsistenan jawaban yang diberikan responden. Namun terlalu banyak ketidakkonsistenan juga tidak diinginkan.

Thomas L. Saaty membuktikan bahwa Indeks Konsistensi dari matriks berordo $\mathrm{n}$ diperoleh rumus sebagai berikut :

$$
\mathrm{CI}=\frac{\lambda_{\max }-\mathrm{n}}{\mathrm{n}-1}
$$

Keterangan :

CI = Consistency Index ( Rasio penyimpangan konsistensi )

$\lambda_{\max }=$ Nilai eigen terbesar dari matriks berordo $\mathrm{n}$

$\mathrm{n} \quad=$ jumlah elemen yang dibandingkan

Nilai $C I$ bernilai nol apabila terdapat standar untuk menyatakan apakah CI menunjukkan matriks yang konsisten. Saaty berpendapat bahwa suatu matriks yang dihasilkan dari perbandingan yang dilakukan secara acak merupakan suatu matriks yang tidak konsisten. Dari matriks acak didapatkan juga nilai Consistency Index yang disebut dengan Random Index (RI). 
Dengan membandingkan CI dengan RI maka didapatkan patokan untuk menentukan tingkat konsistensi suatu matriks yang disebut dengan Consistency Ratio (CR) dengan rumus :

$$
C R=C I / R I
$$

Keterangan :

$$
\begin{array}{ll}
C R & =\text { Consistency Ratio } \\
R I & =\text { Random Index }
\end{array}
$$

\subsection{Analisa Proses Metode AHP (Analytical Hierarchy Process)}

Pada analisa proses untuk penetapan ras ayam serama akan diberikan gambaran lebih jelas mengenai permasalahan yang muncul serta kebutuhan yang diperlukan dalam penetapan rasa yam serama dengan menggunakan software Software Expert Choice.

\section{HASIL DAN PEMBAHASAN}

Pembahasan berikutnya mengenai penguraian hasil penelitian yang dilakukan dalam rangka mengembangkan informasi kualitas ayam serama. Tahapan penelitian tersebut yaitu melakukan uraian hasil metode Analytical Hierarchy Proses (AHP) secara manual, analisis hasil dan pembahasan.

\subsection{Matrik Perbandingan Berpasangan Kriteria}

Pada tahap ini pemberian bobot masing-masing kriteria menggunakan model AHP (Analytical Hieracrchy Process). Data kriteria didapatkan dari kuesioner dan wawancara langsung dengan pemilik reban atau tempat penagkaran ayam serama yang langsung membandingkan kriteria dan kriteria sesuai dengan tabel kepentingan dan sampel matriks perbandingan berpasangan dapat dilihat pada Tabel 3.

Tabel 3. Hasil Perbandingan Kriteria Berpasangan

\begin{tabular}{|c|c|c|c|c|}
\hline Kriteria & Trah ( PE ) & Assesoris( PA ) & Style (PS) & Postur (PP) \\
\hline Trah (PT) & $1 / 1$ & $3 / 1$ & $4 / 1$ & $3 / 1$ \\
\hline Assesoris (PA) & $1 / 3$ & $1 / 1$ & $3 / 1$ & $3 / 1$ \\
\hline Style (PS) & $1 / 4$ & $1 / 3$ & $1 / 1$ & $2 / 1$ \\
\hline Postur (PP) & $1 / 3$ & $1 / 3$ & $1 / 2$ & $1 / 1$ \\
\hline
\end{tabular}

Proses selanjutnya adalah melakukan penjumlahan tiap kolom. Penjumlahan menggunakan 4 (empat) digit dibelakang koma, hal ini berguna untuk pembulatan penghitungan. Adapun hasilnya dapat dilihat pada tabel 4.

Tabel 4. Hasil Bobot Masing-masing Kriteria

\begin{tabular}{|c|c|c|c|c|c|c|}
\hline Kriteria & Trah & Assesoris & Style & Postur & Jumlah & Eigen \\
\hline Trah & 1.0000 & 3.0000 & 4.0000 & 3.0000 & 11.0000 & 0.5019 \\
\hline Assesoris & 0.333 & 1.0000 & 3.0000 & 3.0000 & 7.3333 & 0.3346 \\
\hline Style & 0.2500 & 0.333 & 1.0000 & 2.0000 & 3.5833 & 0.1635 \\
\hline Postur & 0.3333 & 0.3333 & 0.5000 & 1.0000 & 2.1667 & 0.0989 \\
\hline Jumlah & $\mathbf{1 . 5 3 3 3}$ & $\mathbf{4 . 6 6 6 7}$ & $\mathbf{6 . 0 0 0 0}$ & $\mathbf{9 . 0 0 0 0}$ & $\mathbf{2 1 . 9 1 6 7}$ & $\mathbf{1 . 0 0 0 0}$ \\
\hline
\end{tabular}


Citec Journal, Vol. 3, No. 3, Mei 2016 - Juli 2016

Kemudian menghitung hasil kriteria berpasangan kedalam matrik perbandingan berpasangan yang diubah kedalam bentuk desimal.

$$
\begin{aligned}
& \text { Matrik berpasangan } \\
& A=\left(\begin{array}{cccc}
1.000 & 0.3000 & 4.0000 & 3.0000 \\
0.2000 & 1.0000 & 3.0000 & 3.0000 \\
0.2500 & 0.3333 & 1.0000 & 2.0000 \\
0.3333 & 0.3333 & 0.5000 & 1.0000
\end{array}\right) \\
& \left(\begin{array}{cccc}
1.000 & 0.3000 & 4.0000 & 3.0000 \\
0.2000 & 1.0000 & 3.0000 & 3.0000 \\
0.2500 & 0.3333 & 1.0000 & 2.0000 \\
0.3333 & 0.3333 & 0.5000 & 1.0000
\end{array}\right) \times\left(\begin{array}{cccc}
1.000 & 0.3000 & 4.0000 & 3.0000 \\
0.2000 & 1.0000 & 3.0000 & 3.0000 \\
0.2500 & 0.3333 & 1.0000 & 2.0000 \\
0.3333 & 0.3333 & 0.5000 & 1.0000
\end{array}\right) \\
& \left(\begin{array}{cccc}
4.000 & 8.3333 & 18.5000 & 23.0000 \\
2.4167 & 4.0000 & 8.8333 & 13.0000 \\
1.2778 & 2.0833 & 4.0000 & 5.7500 \\
0.9028 & 1.8333 & 3.3333 & 4.0000
\end{array}\right)=\begin{array}{lll} 
\\
=28.8333 & 0.5114 \\
= & 13.1111 & 0.1246 \\
=10.0694 & 0.0957
\end{array}
\end{aligned}
$$

Untuk nilai hasil normalisasi, hasil penjumlahan baris dibagi dengan jumlah keseluruhannya.

\begin{tabular}{|l|l|l|l|l|}
\hline $53.8333 / 105.2639$ & $=$ & 0.5114 & $51 \%$ \\
\hline $28.2500 / 105.2639$ & $=$ & 0.2684 & $27 \%$ \\
\hline $13.1111 / 105.2639$ & $=$ & 0.1246 & $12 \%$ \\
\hline $10.0694 / 105.2639$ & $=$ & 0.0957 & $10 \%$ \\
\hline
\end{tabular}

Kemudian dilakukan perhitungan nilai Eigen maksimum yang diperoleh dengan menjumlahkan hasil perkalian nilai Eigen dengan jumlah kolom.

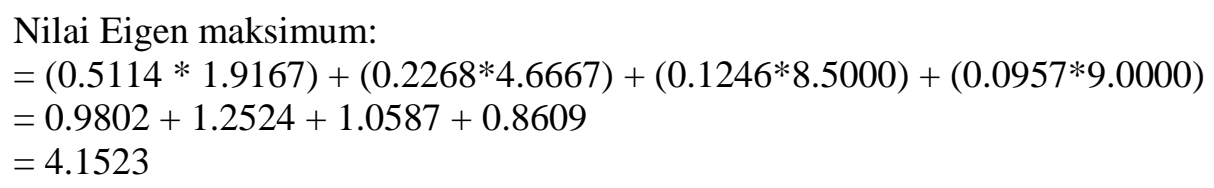

Nilai Consistency Index dengan menggunakan persamaan (1) yaitu:

$$
C I=\frac{4.1523-4}{4-1}=\frac{0.21523}{3}=0.0508
$$

Untuk $n=4, R I$ (random index) $=0.900$ (tabel Saaty), maka dapat diperoleh nilai consistency ratio $(C R)$ dengan menggunakan persamaan (2) yaitu:

$$
C R=\frac{0.0508}{0.900}=0.0627<0.100
$$

$C R<0.1000$ berarti benilai konsisten.

\subsection{Matriks Perbandingan Berpasangan Kriteria Trah}

Pada tahap ini alternatif dibandingkan sesuai dengan kriteria Trah yang datanya didapatkan dari hasil wawancara dan kuesioner kemudian diolah ke dalam matriks perbandingan berpasangan sesuai kriteria. Hasil perhitungan dapat dilihat pada Tabel 5. 
Tabel 5. Hasil Perbandingan Berpasangan Kriteria Trah

\begin{tabular}{|l|r|r|r|r|}
\hline Trah & Ayam A & Ayam B & Ayam C & Ayam D \\
\hline Ayam A & $1 / 1$ & $2 / 1$ & $2 / 1$ & $2 / 1$ \\
\hline Ayam B & $1 / 2$ & $1 / 1$ & $3 / 1$ & $2 / 1$ \\
\hline Ayam C & $1 / 2$ & $1 / 3$ & $1 / 1$ & $2 / 1$ \\
\hline Ayam D & $1 / 2$ & $1 / 2$ & $2 / 1$ & $1 / 1$ \\
\hline
\end{tabular}

Kemudian menghitung hasil kriteria berpasangan kedalam matrik perbandingan berpasangan yang diubah kedalam bentuk desimal.

Matrik berpasangan

$$
A=\left(\begin{array}{llll}
1.0000 & 2.0000 & 2.0000 & 2.0000 \\
0.5000 & 1.0000 & 3.0000 & 2.0000 \\
0.5000 & 0.3333 & 1.0000 & 2.0000 \\
0.5000 & 0.5000 & 0.5000 & 1.0000
\end{array}\right)
$$

Normalisasi Matrik Tahap Pertama

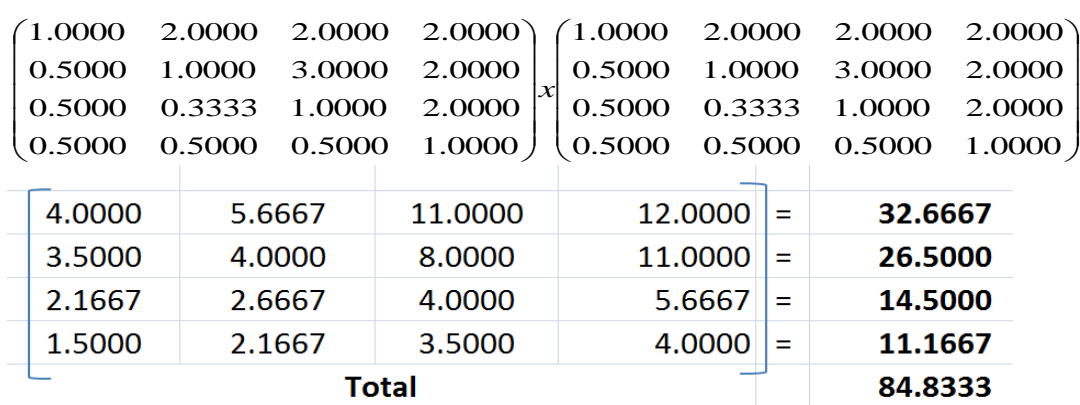

Untuk nilai hasil normalisasi, hasil penjumlahan baris dibagi dengan jumlah keseluruhannya.

\begin{tabular}{|l|l|l|l|l|}
\hline $32.6667 / 84.8333$ & $=$ & $\mathbf{0 . 3 8 5 1}$ & $39 \%$ \\
\hline $26.5000 / 84.8333$ & $=$ & $\mathbf{0 . 3 1 2 4}$ & $31 \%$ \\
\hline $14.5000 / 84.8333$ & $=$ & $\mathbf{0 . 1 7 0 9}$ & $17 \%$ \\
\hline $11.1667 / 84.8333$ & $=$ & $\mathbf{0 . 1 3 1 6}$ & $13 \%$ \\
\hline
\end{tabular}

Normalisasi Matrik Tahap Kedua

\begin{tabular}{|c|c|c|c|c|c|c|c|c|}
\hline 4.0000 & 5.6667 & 11.0000 & 12.0000 & & 4.0000 & 5.6667 & 11.0000 & 12.0000 \\
\hline 3.5000 & 4.0000 & 8.0000 & 11.0000 & \multirow{2}{*}{$\mathrm{x}$} & 3.5000 & 4.0000 & 8.0000 & 11.0000 \\
\hline 2.1667 & 2.6667 & 4.0000 & 5.6667 & & 2.1667 & 2.6667 & 4.0000 & 5.6667 \\
\hline 1.5000 & 2.1667 & 3.5000 & 4.0000 & & 1.5000 & 2.1667 & 3.5000 & 4.0000 \\
\hline- & & & \multicolumn{2}{|l|}{$\neg$} & \multicolumn{2}{|l|}{ L } & & \\
\hline 77.6667 & 100.6667 & 175.3333 & 220.6667 & $=$ & 574.3333 & 0.3834 & & \\
\hline 61.8333 & 81.0000 & 141.0000 & 175.3333 & $=$ & 459.1667 & 0.3065 & & \\
\hline 35.1667 & 45.8889 & 81.0000 & 100.6667 & $=$ & 262.7222 & 0.1754 & & \\
\hline 27.1667 & 35.1667 & 61.8333 & 77.6667 & $=$ & 201.8333 & 0.1347 & & \\
\hline & \multicolumn{3}{|c|}{ Total } & & 1498.0556 & & & \\
\hline
\end{tabular}


Citec Journal, Vol. 3, No. 3, Mei 2016 - Juli 2016

ISSN: 2354-5771

Normalisasi Matrik Tahap Ketiga

\begin{tabular}{|c|c|c|c|c|c|c|c|c|}
\hline 77.6667 & 100.6667 & 175.3333 & 220.6667 & & 77.6667 & 100.6667 & 175.3333 & 220.6667 \\
\hline 61.8333 & 81.0000 & 141.0000 & 175.3333 & \multirow{3}{*}{$x$} & 61.8333 & 81.0000 & 141.0000 & 175.3333 \\
\hline 35.1667 & 45.8889 & 81.0000 & 100.6667 & & 35.1667 & 45.8889 & 81.0000 & 100.6667 \\
\hline 27.1667 & 35.1667 & 61.8333 & 77.6667 & & 27.1667 & 35.1667 & 61.8333 & 77.6667 \\
\hline \multicolumn{2}{|c|}{ DIBAGI } & & & & & & & \\
\hline 24417.3333 & 31778.4074 & 55658.1111 & 69577.3333 & $=$ & $181,431.1852$ & 0.3835 & & \\
\hline 19532.6111 & 25421.7778 & 44524.8889 & 55658.1111 & $=$ & $145,137.3889$ & 0.3068 & & \\
\hline 11152.0185 & 14514.2222 & 25421.7778 & 31778.4074 & $=$ & $82,866.4259$ & 0.1752 & & \\
\hline 8568.8333 & 11152.0185 & 19532.6111 & 24417.3333 & $=$ & $63,670.7963$ & 0.1346 & & \\
\hline \multicolumn{4}{|c|}{ Total } & & $473,105.7963$ & & & \\
\hline
\end{tabular}

Proses selanjutnya adalah melakukan penjumlahan tiap kolom. Penjumlahan menggunakan 4 (empat) digit dibelakang koma, hal ini berguna untuk pembulatan penghitungan. Adapun hasilnya dapat dilihat pada Tabel 6.

Tabel 6. Hasil Bobot Masing-masing Kriteria Trah

\begin{tabular}{|l|l|l|l|l|l|}
\hline Trah & Ayam A & Ayam B & Ayam C & Ayam D & Nilai Eigen \\
\hline Ayam A & $\mathbf{1 . 0 0 0 0}$ & 3.0000 & 2.0000 & 1.0000 & 0.3835 \\
\hline Ayam B & $\mathbf{0 . 3 3 3 3}$ & 1.0000 & 0.2000 & 0.5000 & 0.3068 \\
\hline Ayam C & $\mathbf{0 . 5 0 0 0}$ & 5.0000 & 1.0000 & 2.0000 & 0.1752 \\
\hline Ayam D & $\mathbf{1 . 0 0 0 0}$ & 2.0000 & 0.5000 & 1.0000 & 0.1346 \\
\hline Jumlah & $\mathbf{2 . 8 3 3 3}$ & $\mathbf{1 1 . 0 0 0 0}$ & $\mathbf{3 . 7 0 0 0}$ & $\mathbf{4 . 5 0 0 0}$ & $\mathbf{1 . 0 0 0 0}$ \\
\hline
\end{tabular}

Menghitung Nilai Eigen maksimum:

$=(0.3835 * 2.8333)+(0.3068 * 3.8333)+(0.1752 * 6.5000)+(0.1346 * 7.0000)$

$=(0.9587+1.1760+1.1385+0.9421)$

$=4.2153$

Nilai Consistency Index dengan menggunakan persamaan (1) yaitu:

$$
\begin{aligned}
C I=4.2153-\underline{-4} & =0.2153=0.0718 \\
4-1 & =3
\end{aligned}
$$

Untuk $n=4$, RI (random index) $=0,900$ (tabel Saaty), maka dapat diperoleh nilai consistency ratio (CR) dengan menggunakan persamaan (2) yaitu:

$$
C R=\frac{0.0718}{0.900}=0.0886<0.1000 .
$$

Karena $C R<0.1000$ berarti nilai konsisten.

Diperoleh skala prioritas untuk masing-masing kriteria. Pada baris pertama untuk penilaian Ekonomi Sosial dengan nilai 0.3889 atau 39\%, baris kedua Infrastruktur kebutuhan dasar dengan nilai 0.1235 atau 12\% dan baris ketiga Hasil Alam Daerah dengan nilai 0.2995 atau $30 \%$, dan Kewilayahan \& Kependudukan 0.1881 atau $19 \%$. 


\subsection{Matriks Perbandingan Berpasangan Kriteria Postur}

Pada tahap ini alternatif dibandingkan sesuai dengan kriteria Postur yang datanya didapatkan dari hasil wawancara dan kuesioner kemudian diolah ke dalam matriks perbandingan berpasangan sesuai kriteria. Hasil perhitungan dapat dilihat pada Tabel 7.

Tabel 7. Hasil Perbandingan Berpasangan Kriteria Postur

\begin{tabular}{|l|r|r|r|r|}
\hline Postur & \multicolumn{1}{|c|}{ Ayam A } & \multicolumn{1}{|c|}{ Ayam B } & \multicolumn{1}{|c|}{ Ayam C } & \multicolumn{1}{c|}{ Ayam D } \\
\hline Ayam A & $1 / 1$ & $2 / 1$ & $2 / 1$ & $3 / 1$ \\
\hline Ayam B & $1 / 2$ & $1 / 1$ & $2 / 1$ & $3 / 2$ \\
\hline Ayam C & $1 / 2$ & $1 / 2$ & $1 / 1$ & $3 / 1$ \\
\hline Ayam D & $1 / 3$ & $1 / 3$ & $1 / 3$ & $1 / 1$ \\
\hline
\end{tabular}

Kemudian menghitung hasil kriteria berpasangan kedalam matrik perbandingan berpasangan yang diubah kedalam bentuk desimal.

$$
A=\left(\begin{array}{llll}
1.0000 & 2.0000 & 2.0000 & 3.0000 \\
0.5000 & 1.0000 & 2.0000 & 3.0000 \\
0.5000 & 0.5000 & 1.0000 & 3.0000 \\
0.3333 & 0.3333 & 0.3333 & 1.0000
\end{array}\right)
$$

Normalisasi Matrik Tahap Pertama

\begin{tabular}{|c|c|c|c|c|c|c|c|c|}
\hline 1.0000 & 2.0000 & 2.0000 & 3.0000 & & 1.0000 & 2.0000 & 2.0000 & 3.0000 \\
\hline 0.5000 & 1.0000 & 2.0000 & 3.0000 & \multirow{2}{*}{$X$} & 0.5000 & 1.0000 & 2.0000 & 3.0000 \\
\hline 0.5000 & 0.5000 & 1.0000 & 3.0000 & & 0.5000 & 0.5000 & 1.0000 & 3.0000 \\
\hline 0.3333 & 0.3333 & 0.3333 & 1.0000 & & 0.3333 & 0.3333 & 0.3333 & 1.0000 \\
\hline 4.0000 & 6.0000 & 9.0000 & 18.0000 & $=$ & 37.0000 & 0.4100 & & \\
\hline 3.0000 & 4.0000 & 6.0000 & 13.5000 & $=$ & 26.5000 & 0.2936 & & \\
\hline 2.2500 & 3.0000 & 4.0000 & 9.0000 & $=$ & 18.2500 & 0.2022 & & \\
\hline 1.0000 & 1.5000 & 2.0000 & 4.0000 & $=$ & 8.5000 & 0.0942 & & \\
\hline & To & & & & 90.2500 & & & \\
\hline
\end{tabular}

Normalisasi Matrik Tahap Kedua

\begin{tabular}{|c|c|c|c|c|c|c|c|c|}
\hline 4.0000 & 6.0000 & 9.0000 & 18.0000 & & 4.0000 & 6.0000 & 9.0000 & 18.0000 \\
\hline 3.0000 & 4.0000 & 6.0000 & 13.5000 & \multirow{2}{*}{$x$} & 3.0000 & 4.0000 & 6.0000 & 13.5000 \\
\hline 2.2500 & 3.0000 & 4.0000 & 9.0000 & & 2.2500 & 3.0000 & 4.0000 & 9.0000 \\
\hline 1.0000 & 1.5000 & 2.0000 & 4.0000 & & 1.0000 & 1.5000 & 2.0000 & 4.0000 \\
\hline \multicolumn{9}{|l|}{ L } \\
\hline 72.2500 & 102.0000 & 144.0000 & 306.0000 & $=$ & 624.2500 & 0.4093 & & \\
\hline 51.0000 & 72.2500 & 102.0000 & 216.0000 & $=$ & 441.2500 & 0.2893 & & \\
\hline 36.0000 & 51.0000 & 72.2500 & 153.0000 & $=$ & 312.2500 & 0.2048 & & \\
\hline 17.0000 & 24.0000 & 34.0000 & 72.2500 & $=$ & 147.2500 & 0.0966 & & \\
\hline \multicolumn{4}{|c|}{ Total } & & 1525.0000 & & & \\
\hline
\end{tabular}

Normalisasi Matrik Tahap Ketiga

\begin{tabular}{|c|c|c|c|c|c|c|c|c|}
\hline 72.2500 & 102.0000 & 144.0000 & 306.0000 & & 72.2500 & 102.0000 & 144.0000 & 306.0000 \\
\hline 51.0000 & 72.2500 & 102.0000 & 216.0000 & \multirow{2}{*}{$\mathrm{x}$} & 51.0000 & 72.2500 & 102.0000 & 216.0000 \\
\hline 36.0000 & 51.0000 & 72.2500 & 153.0000 & & 36.0000 & 51.0000 & 72.2500 & 153.0000 \\
\hline 17.0000 & 24.0000 & 34.0000 & 72.2500 & & 17.0000 & 24.0000 & 34.0000 & 72.2500 \\
\hline \multicolumn{2}{|c|}{ DIBAGI } & & & & & & & \\
\hline 20808.0625 & 29427.0000 & 41616.0000 & 88281.0000 & $=$ & $180,132.0625$ & 0.4094 & & \\
\hline 14713.5000 & 20808.0625 & 29427.0000 & 62424.0000 & $=$ & $127,372.5625$ & 0.2895 & & \\
\hline 10404.0000 & 14713.5000 & 20808.0625 & 44140.5000 & $=$ & $90,066.0625$ & 0.2047 & & \\
\hline 4904.5000 & 6936.0000 & 9809.0000 & 20808.0625 & $=$ & $42,457.5625$ & 0.0965 & & \\
\hline \multicolumn{4}{|c|}{ Total } & & $440,028.2500$ & & & \\
\hline
\end{tabular}


Citec Journal, Vol. 3, No. 3, Mei 2016 - Juli 2016

ISSN: 2354-5771

Proses selanjutnya adalah melakukan penjumlahan tiap kolom. Penjumlahan menggunakan 4 (empat) digit dibelakang koma, hal ini berguna untuk pembulatan penghitungan.

Tabel 8. Hasil Bobot Masing-masing Kriteria Postur

\begin{tabular}{|l|c|c|c|c|c|c|}
\hline Postur & Ayam A & Ayam B & Ayam C & Ayam D & Nilai Eigen & Bobot \\
\hline Ayam A & 1.0000 & 3.0000 & 2.0000 & 1.0000 & 0.4094 & $41 \%$ \\
\hline Ayam B & 0.3333 & 1.0000 & 0.2000 & 0.5000 & 0.2895 & $29 \%$ \\
\hline Ayam C & 0.5000 & 5.0000 & 1.0000 & 2.0000 & 0.2047 & $20 \%$ \\
\hline Ayam D & 1.0000 & 2.0000 & 0.5000 & 1.0000 & 0.0965 & $10 \%$ \\
\hline Jumlah & 2.8333 & 11.0000 & 3.7000 & 4.5000 & 1.0000 & $100 \%$ \\
\hline
\end{tabular}

Menghitung Nilai Eigen maksimum:

$=(0.4094 * 2.3333)+(0.2895 * 3.8333)+(0.2047 * 5.3333)+(0.0965 * 10.000)$

$=(0.9552+1.1096+1.0196+0.9649)$

$=4.1213$

Nilai Consistency Index dengan menggunakan persamaan (1) yaitu:

$C I=4.1213 \underline{-4}=0.1213_{-} \quad=0.0404$

$$
4-1 \quad 3
$$

Untuk $n=4$, RI (random index) $=0,900$ (tabel Saaty), maka dapat diperoleh nilai consistency ratio $(\mathrm{CR})$ dengan menggunakan persamaan (2) yaitu:

$C R=\underline{0.0718}=0.0449<0.1000$.

0.900

Karena $C R<0.1000$ berarti nilai konsisten.

\subsection{Matriks Perbandingan Berpasangan Kriteria Assesoris}

Pada tahap ini alternatif dibandingkan sesuai dengan kriteria assesoris antar kualitas ayam serama yang datanya didapatkan dari hasil wawancara dan kuesioner kemudian diolah ke dalam matriks perbandingan berpasangan sesuai kriteria. Hasil perhitungan dapat dilihat pada Tabel 9.

Tabel 9. Hasil Perbandingan Berpasangan Kriteria Assesoris

\begin{tabular}{|l|c|c|c|c|}
\hline Assesoris & Ayam A & Ayam B & Ayam C & Ayam D \\
\hline Ayam A & $1 / 1$ & $3 / 1$ & $3 / 1$ & $5 / 1$ \\
\hline Ayam B & $1 / 3$ & $1 / 1$ & $2 / 1$ & $3 / 1$ \\
\hline Ayam C & $1 / 3$ & $1 / 2$ & $1 / 1$ & $3 / 1$ \\
\hline Ayam D & $1 / 5$ & $1 / 3$ & $1 / 3$ & $1 / 1$ \\
\hline
\end{tabular}

Kemudian menghitung hasil kriteria berpasangan kedalam matrik perbandingan berpasangan yang diubah kedalam bentuk desimal.

Matrik berpasangan Matrik berpasangan

$\mathrm{A}=\left(\begin{array}{llll}1.0000 & 3.0000 & 3.0000 & 5.0000 \\ 0.3333 & 1.0000 & 2.0000 & 3.0000 \\ 0.3333 & 0.5000 & 1.0000 & 3.0000 \\ 0.2000 & 0.3333 & 0.3333 & 1.0000\end{array}\right)$ 
Normalisasi Matrik Tahap Pertama

\begin{tabular}{|c|c|c|c|c|c|c|c|c|}
\hline 1.0000 & 3.0000 & 3.0000 & 5.0000 & & 1.0000 & 3.0000 & 3.0000 & 5.0000 \\
\hline 0.3333 & 1.0000 & 2.0000 & 3.0000 & \multirow{3}{*}{$X$} & 0.3333 & 1.0000 & 2.0000 & 3.0000 \\
\hline 0.3333 & 0.5000 & 1.0000 & 3.0000 & & 0.3333 & 0.5000 & 1.0000 & 3.0000 \\
\hline 0.2000 & 0.3333 & 0.3333 & 1.0000 & & 0.2000 & 0.3333 & 0.3333 & 1.0000 \\
\hline 4.0000 & 9.1667 & 13.6667 & 28.0000 & $=$ & 54.8333 & 0.5172 & & \\
\hline 1.9333 & 4.0000 & 6.0000 & 13.6667 & $=$ & 25.6000 & 0.2415 & & \\
\hline 1.4333 & 3.0000 & 4.0000 & 9.1667 & $=$ & 17.6000 & 0.1660 & & \\
\hline 0.6222 & 1.4333 & 1.9333 & 4.0000 & $=$ & 7.9889 & 0.0754 & & \\
\hline \multicolumn{5}{|c|}{ Total } & 106.0222 & & & \\
\hline
\end{tabular}

Normalisasi Matrik Tahap Kedua

\begin{tabular}{|c|c|c|c|c|c|c|c|c|}
\hline 4.0000 & 9.1667 & 13.6667 & 28.0000 & & 4.0000 & 9.1667 & 13.6667 & 28.0000 \\
\hline 1.9333 & 4.0000 & 6.0000 & 13.6667 & & 1.9333 & 4.0000 & 6.0000 & 13.6667 \\
\hline 1.4333 & 3.0000 & 4.0000 & 9.1667 & & 1.4333 & 3.0000 & 4.0000 & 9.1667 \\
\hline 0.6222 & 1.4333 & 1.9333 & 4.0000 & & 0.6222 & 1.4333 & 1.9333 & 4.0000 \\
\hline 70.7333 & 154.4667 & 218.4667 & 474.5556 & $=$ & 918.2222 & \multicolumn{2}{|c|}{0.5167} & \\
\hline 32.5704 & 71.3111 & 100.8444 & 218.4667 & $=$ & 423.1926 & \multicolumn{2}{|c|}{0.2381} & \\
\hline 22.9704 & 50.2778 & 71.3111 & 154.4667 & $=$ & 299.0259 & \multicolumn{2}{|c|}{0.1683} & \\
\hline 10.5200 & 22.9704 & 32.5704 & 70.7333 & $=$ & 136.7941 & \multicolumn{2}{|c|}{0.0770} & \\
\hline & \multicolumn{2}{|c|}{ Total } & & & 1777.2348 & & & \\
\hline
\end{tabular}

Normalisasi Matrik Tahap Ketiga

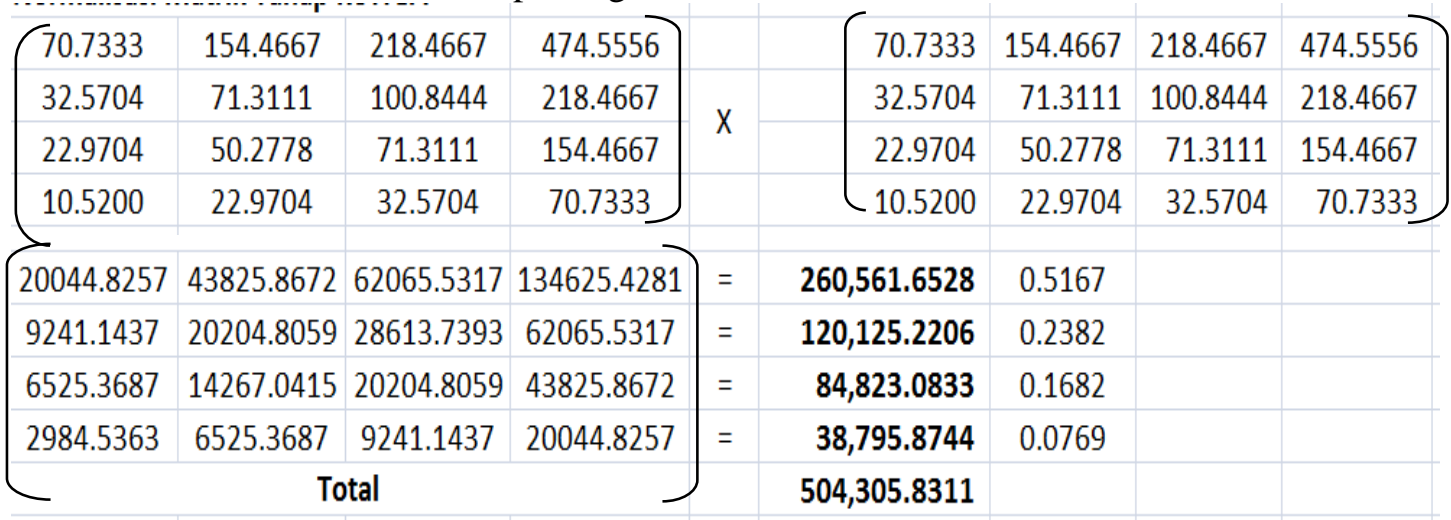

Tabel 10. Hasil Bobot Masing-masing Kriteria Assesoris

\begin{tabular}{|c|c|c|c|c|c|c|}
\hline $\begin{array}{l}\text { Personal/ } \\
\text { deskripsi diri }\end{array}$ & Ayam A & Ayam B & Ayam C & Ayam D & Nilai Eigen & Bobot \\
\hline Ayam A & 1.0000 & 3.0000 & 2.0000 & 1.0000 & 0.5167 & $52 \%$ \\
\hline Ayam B & 0.3333 & 1.0000 & 0.2000 & 0.5000 & 0.2382 & $24 \%$ \\
\hline Ayam C & 0.5000 & 5.0000 & 1.0000 & 2.0000 & 0.1682 & $17 \%$ \\
\hline Ayam D & 1.0000 & 2.0000 & 0.5000 & 1.0000 & 0.0769 & $8 \%$ \\
\hline Jumlah & $\mathbf{2 . 8 3 3 3}$ & $\mathbf{1 1 . 0 0 0 0}$ & $\mathbf{7 . 0 0 0 0}$ & $\mathbf{4 . 5 0 0 0}$ & $\mathbf{1 . 0 0 0 0}$ & $\mathbf{1 0 0 \%}$ \\
\hline
\end{tabular}

Menghitung Nilai Eigen maksimum:

$=(0.5167 * 2.8333)+(0.2382 * 11.0000)+(0.1682 * 3.7000)+(0.0769 * 4.7000)$

$=0.9645+1.1513+1.0653+0.9232$

$=4.1042$ 
Citec Journal, Vol. 3, No. 3, Mei 2016 - Juli 2016

Nilai Consistency Index dengan menggunakan persamaan (1) yaitu:

$$
C I=\frac{4.1042-4}{4-1}=0.1042_{-}=0.0347
$$

Untuk $n=4$, RI (random index) $=0,900$ (tabel Saaty), maka dapat diperoleh nilai consistency ratio (CR) dengan menggunakan persamaan (2) yaitu:

$$
C R=\underline{0.0347}=0.0429<0.1000 .
$$

Karena $C R<0.1000$ berarti nilai konsisten.

\subsection{Analisa Hasil Metode Analytical Hierarchy Process}

Setelah mendapatkan kriteria pendukung dari masing-masing kriteria, langkah selanjutnya adalah mengalikan nilai tersebut dengan nilai akhir dari bobot kriteria. Dari hasil akhir perkalian matrik tersebut, maka dapat dilihat kriteria setiap ayam seperti pada Tabel 11, yaitu untuk Ayam A dengan nilai 0.4603 atau 46\%, Ayam B dengan nilai 0.3163 atau 31\%, Ayam C dengan nilai 0.2005 atau 20\%, serta Ayam D dengan nilai 0.1218 atau 12\%.

Tabel 11. Tabel Nilai Masing-masing Kriteria

\begin{tabular}{|l|l|c|l|c|c|c|}
\hline Bobot & Trah & Assesoris & Style & Postur & Bobot Final & Rank \\
\hline Ayam A & 0.3835 & 0.4049 & 0.5167 & 0.4688 & 0.4603 & 1 \\
\hline Ayam B & 0.3068 & 0.2895 & 0.2382 & 0.2683 & 0.3163 & 2 \\
\hline Ayam C & 0.1752 & 0.2047 & 0.1682 & 0.1681 & 0.2005 & 3 \\
\hline Ayam D & 0.1346 & 0.0965 & 0,0769 & 0.0947 & 0.1218 & 4 \\
\hline
\end{tabular}

Hasil analisa menyatakan alternatif yang terpilih paling mendukung untuk ayam serama yang terpopuler atau berkualitas layak adalah:

1. Ayam A (Peringkat Pertama)

2. Ayam B (Peringkat Kedua)

3. Ayam C (Peringkat Ketiga)

4. Ayam D (Peringkat Keempat)

\subsection{Penerapan Expert Choice}

Adapun hasil dari analisi dan perancangan yang telah di coba secara manual telah dinyatakan berhasil, maka langkah selanjutnya pengujian dengan menggunakan software expert choice. Hasil pengujian setiap kriteria ditunjukkan pada Gambar 2, Gambar 3, Gambar 4, dan Gambar 5, sedangkan hasil akhir keberhasilan penetapan ras ayam ditunjukkan pada Gambar 6.
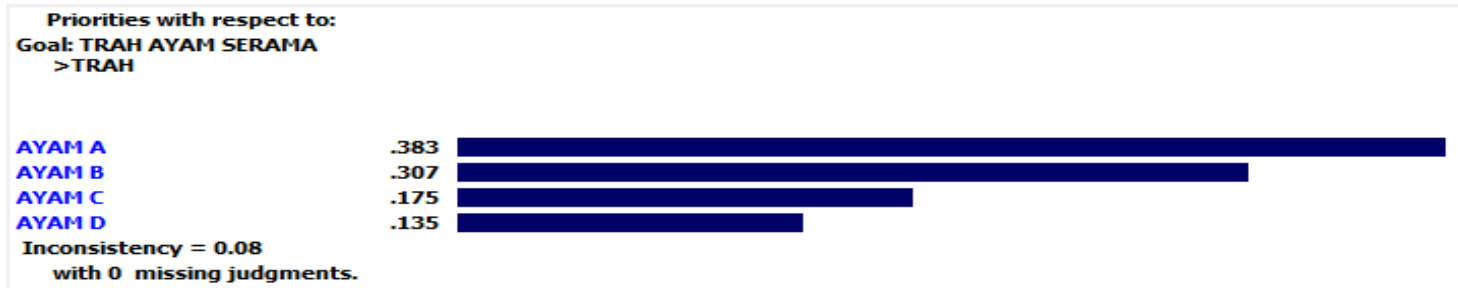

Gambar 2.Hasil Perbandingan Kriteria Trah 
Priorities with respect to: Goal: TRAH AYAM SERAMA $>$ ASSESORIS

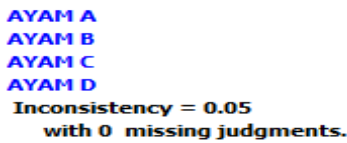

Gambar 3.Hasil Perbandingan Kriteria Assesories

289

205

.096

Priorities with respect to: Goal: TRAH AYAM SERAMA $>$ STYLE

\section{AYAM A}

AYAM B

AYAM C

AYAM D

Inconsistency $=0.04$

with 0 missing judgments.

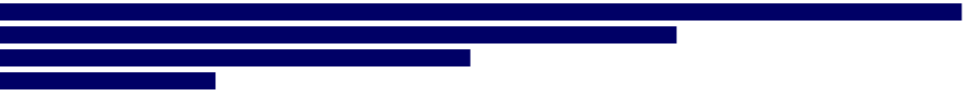

Gambar 4.Hasil Perbandingan Kriteria Style

Priorities with respect to:
Goal: TRAH AYAM SERAMA
> POSTUR
AYAM A
AYAM B
AYAM C
AYAM D
Inconsistency $=0.07$
with 0 missing judgments.
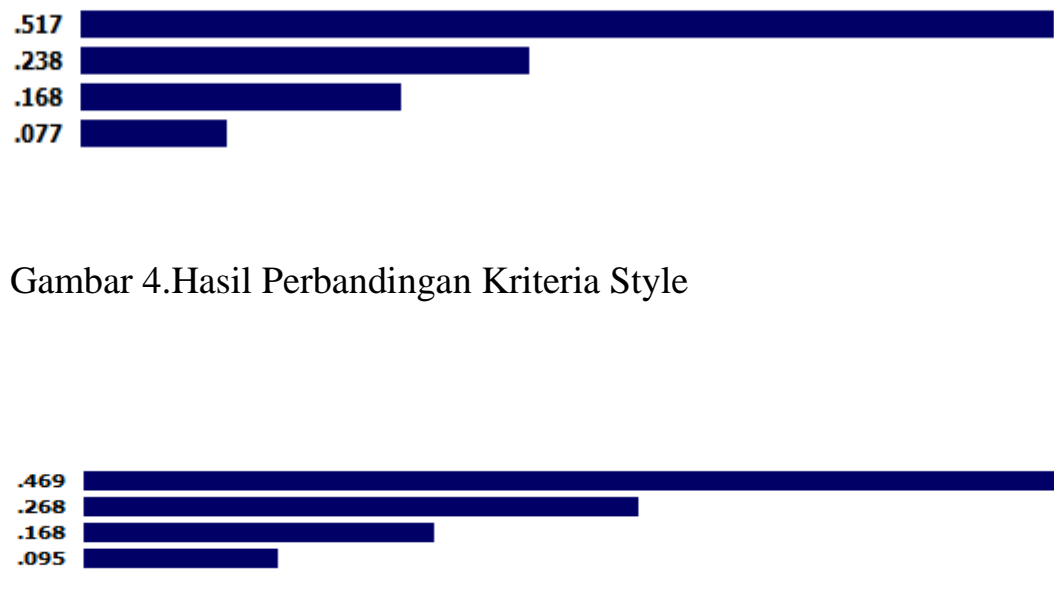

Gambar 5.Hasil Perbandingan Kriteria Postur

Priorities with respect to:
Goal: TRAH AYAM SERAMA
TRAH
ASSESORIS
STYLE
POSTUR
Inconsistency $=\mathbf{0 . 0 8}$
$\quad$ with 0 missing judgments.

Gambar 6. Goal keberhasilan Penetapan Ras Ayam Serama

\section{KESIMPULAN}

Dari hasil analisa sistem pendukung keputusan pada CMF (Cah Medan Farm) dalam menetapkan ras ayam serama dengan menggunakan metode Analytical Hierarchy Process (AHP), dapat disimpulkan bahwa:

1. Sistem Pendukung Keputusan yang dibuat dengan menggunakan metode AHP dapat melakukan perhitungan secara otomatis ketika pengguna menginputkan nilai dan bobot, sehingga dapat mengurangi masalah dalam pengambilan keputusan dalam penetapan ras ayam serama.

2. Software super decisions telah dapat memenuhi kebutuhan untuk membantu dalam penentapan rasa yam serama yang paling sesuai dengan kriteria-kriteria yang telah ditentukan oleh pihak standarisasi penilaian ayam serama Malaysia. 


\section{SARAN}

Berdasarkan hasil pengujian dan kesimpulan, saran untuk penetapan dan kelanjutan sistem pendukung keputusan ini adalah bagi para peneliti yang ingin mengembangkan sistem pendukung keputusan ini dapat dikembangkan lagi menjadi lebih baik dan lebih bervariasi dengan melengkapi dan menambah cluster beserta node untuk kriteria-kriteria ayam serama, agar hasil analisa lebih tajam dan valid.

\section{DAFTAR PUSTAKA}

[1] Ruswinarno, A., Hadiiswa, 2011, Serama Ayam Mungil Nan Eksotik, Penerbit Agromedia Pustaka, Jakarta Selatan.

[2] Ellya Sestri, 2013, Penerapan Metode Analitycal Hierarchy Process (AHP) Pada Sistem Pendukung Keputusan Penilaian Kinerja Dosen Berkualitas, Jurnal Liquidity, No. 1, Vol. 2 , Hal. 100-109.

[3] Ngatawi, Setyaningsih, I., 2011, Analisis Pemilihan Supplier Menggunakan Metode Analytical Hierarchy Process (AHP), Jurnal Ilmiah Teknik Industri, No. 1, Vol. 10, Hal 7-13.

[4] Dyah N. R., Maulana, A., 2009, Sistem Pendukung Keputusan Perancanaan Strategis Kinerja Instansi Pemerintah Menggunakan Metode Analitycal Hierarchy Process (AHP), Jurnal Informatika, Vol 3, No.2.

[5] Sonatha, Y., Azmi, M., 2010, Penerapan Metode AHP dalam Menentukan Mahasiswa Berprestasi, Poli Rekayasa, No. 2, Vol. 5, Hal 128-136.

[6] Ginting, M., Pelawi, P., 2011, Sistem Pendukung Keputusan Berbasis Spread Sheet untuk pemilihan staf Administrasi Berprestasi di Lingkungan STMIK-STIE Mikro Skil Medan Dengan Metode AHP, Jurnal Wira Ekonomi Mikroskill, No. 1, Vol. 1, Hal. 37-45.

[7] Wolo, P., Chandra, C. J., 2014, Analisis Dan Solusi Sistem Untuk Mendukung Keputusan Penilaian Kinerja Guru Menggunakan Metode Analytical Hierarchy Process (Ahp) Pada Smk Negeri 1 Maumere. Jurnal in Create (Inovasi dan Kreasi dalam Teknologi Informasi), No. 1, Vol. 1, Hal 1-11.

[8] Saaty, T. L., 2008, Decision Making with the Analytic Hierarchy Process. Int. J. Services Sciences, No. 1, Vol. 1, Hal 83 - 98.

[9] Saragih, S. H., 2013, Penerapan Metode Analytical Hierarchi Process (AHP) Pada Sistem Pendukung Keputusan Pemilihan Laptop, Pelita Informatika Budi Darma, No. 2, Vol. 4, Hal 82-88. 